\title{
Interleukin 3 Promotes the In Vitro Proliferation of Murine Pluripotent Hematopoietic Stem Cells
}

\author{
Jerry L. Spivak, Robert R. L. Smith, and James N. Ihle \\ Division of Hematology, Department of Medicine, and Department of Pathology, The Johns Hopkins University School of Medicine, \\ Baltimore, Maryland 21205; National Cancer Institute, Frederick Cancer Research Facility, Frederick, Maryland 21701
}

\begin{abstract}
Medium conditioned by activated $T$ lymphocytes stimulates the in vitro proliferation of pluripotent hematopoietic stem cells (spleen colony-forming units [CFU-S]) but the factors involved have not been identified. Because the lymphokine interleukin 3 (IL-3) enhances in vitro colony formation by committed hematopoietic progenitor cells, we examined the effect of IL-3 on the in vitro proliferation of CFU-S using an 11-d spleen colony assay. When mouse marrow cells were placed in liquid culture, CFU$\mathrm{S}$ content declined progressively and by $96 \mathrm{~h}$ only $13 \%$ of the CFU-S remained. By contrast, after $96 \mathrm{~h}$ in the presence of 20 $\mathrm{U} / \mathrm{ml}$ of IL-3, the number of CFU-S were the same as that in the initial inoculum. Although the number of CFU-S eventually declined, they could still be recovered after $264 \mathrm{~h}$ of culture. In the absence of IL-3, the number of CFU-S synthesizing DNA was negligible; in its presence, $>\mathbf{2 0} \%$ of the CFU-S were in cycle. IL-3 stimulated CFU-S proliferation at a concentration of 0.2 $\mathrm{U} / \mathrm{ml}$. The dose-response curve was similar to that observed for other biologic effects of the lymphokine, and as little as $1 \mathrm{~h}$ of exposure to IL-3 enhanced the survival of CFU-S in vitro. Treatment of marrow cells with anti-Thy 1.2 antibody and complement before exposure to IL-3 did not inhibit spleen colony formation, but treatment of the cells with anti-Thy 1.2 antibody and complement after exposure to IL-3 reduced CFU-S recovery after $96 \mathrm{~h}$ of culture by $45 \%$. The cell composition of day 11 spleen colonies formed by IL-3-treated marrow cells was similar to that of colonies formed by untreated marrow cells. Finally, day 11 CFU-S persisting in the marrow of mice treated with 5-fluorouracil required IL-3 for proliferation in vitro. Taken together, these data indicate that IL-3 promotes the proliferation of CFU$S$ in vitro, increases the number of CFU-S synthesizing DNA, but does not alter their commitment program, and the target cell population includes CFU-S with self-renewal and marrow-repopulating ability.
\end{abstract}

\section{Introduction}

Under normal circumstances, the maturation of hematopoietic cells within the bone marrow proceeds serially from primitive progenitors to the differentiated, formed elements that circulate

Portions of this work were presented at the annual meeting of the American Society of Hematology, December 1984, and have been published as an abstract (1984. Blood. 64[Suppl. 1]:136a).

Address reprint requests to Dr. Spivak, Division of Hematology, Blalock 1033, The Johns Hopkins Hospital, Baltimore, MD 21205.

Received for publication 20 February 1985.

J. Clin. Invest.

(c) The American Society for Clinical Investigation, Inc.

0021-9738/85/10/1613/09 \$1.00

Volume 76, October 1985, 1613-1621 in the peripheral blood. Among the primitive hematopoietic progenitor cells, which are morphologically unrecognizable and constitute only a minor fraction of the total marrow cell population, a hierarchy has been identified using clonal assays and isoenzymes or chromosomal markers. Within this hierarchy, the various progenitor cells differ in their capacity for self-renewal and lineage-specific differentiation. The proliferation and terminal differentiation of lineage-restricted hematopoietic progenitor cells appear to be regulated by specific glycoproteins. The mechanisms involved in the regulation of more primitive pluripotent hematopoietic progenitor cells that retain the capacity for self-renewal are less well understood.

Normally, only a minor fraction of pluripotent stem cells in the marrow are in active cell cycle (1). An increase in the number of cycling marrow stem cells both in vivo and in vitro occurs in response to population depletion (2) and after exposure to certain hormones and adrenergic or cholinergic agonists (3), but the mechanisms involved are unknown. Cerny (4) was the first to demonstrate that products of activated $\mathrm{T}$ lymphocytes stimulate the proliferation of pluripotent hematopoietic stem cells. His observations have been amply confirmed by both in vitro and in vivo clonal assays for stem cells with a capacity for self-renewal (5-8). In addition, the in vitro proliferation of certain lineagerestricted erythroid, myeloid, and megakaryocytic progenitor cells is also supported by medium conditioned by activated $\mathrm{T}$ lymphocytes $(9,10)$ but the factor or factors responsible have not been completely characterized.

Recently, the lymphokine interleukin 3 (IL-3) ${ }^{1}$ was purified to apparent biochemical homogeneity from medium conditioned by WEHI-3 cells (11). IL-3, which induces the enzyme $20 \alpha$ hydroxysteroid dehydrogenase in splenic lymphocytes of the nude mouse, is also produced by $\mathrm{T}$ lymphocytes after exposure to mitogens (12). Preliminary studies have indicated that IL-3 promotes the proliferation of primitive erythroid (BFU-E), megakaryocytic (CFU-Meg), and granulocyte-macrophage progenitor cells (CFU-GM), and mast cells (13-15). It may also enhance the proliferation of pluripotent hematopoietic stem cells (spleen colony-forming units [CFU-S]) $(14,16)$. In this regard, Rennick et al. (17) have demonstrated the cloned gene product of a cDNA encoding for mast cell growth factor, which has extensive amino acid sequence homology with IL-3, also promotes the in vitro proliferation of CFU-S. In this report, we describe the interaction of IL-3 and pluripotent hematopoietic stem cells using the spleen colony assay. Our data indicate that IL-3 promotes the in vitro survival of CFU-S, increases the number of CFU-S in cell cycle, but does not alter their commitment program, and the population of CFU-S responding to IL-3 appears

1. Abbreviations used in this paper: BFU-E, erythroid progenitor cell (burst-forming unit); CFU-GM, granulocyte-macrophage progenitor cell (colony-forming unit); CFU-S, spleen colony-forming unit; 5-FU, 5-fluorouracil; IL-3, interleukin 3; TdR, thymidine. 
to include CFU-S with self-renewal and marrow-repopulating ability.

\section{Methods}

Animals. $\mathrm{B}_{6} \mathrm{D}_{2} \mathrm{~F}_{1}$ mice, 6-10 wk of age, (Jackson Laboratories, Bar Harbor, ME) were used in these studies. The mice were housed in sterile cages in groups of five from the time of delivery and given standard laboratory diet and acidified water ad libitum. Both male and female mice were used in that no gender-related differences in spleen colonyforming activity in response to IL-3 were observed.

Cell culture. Mice were killed by cervical dislocation and marrow cells were flushed from the femurs with Hepes-buffered (10 mM Hepes) RPMI medium (Gibco Laboratories, Grand Island, NY) and 10\% fetal calf serum (Sterile Systems, Logan, UT) into sterile polystyrene tubes and dispersed into single cells by repeated aspiration through a 22-gauge needle. The cell suspension was centrifuged at $400 \mathrm{~g}$ for $5 \mathrm{~min}$ at room temperature and resuspended at a concentration of $1 \times 10^{6}$ cells $/ \mathrm{ml}$ in Hepes-buffered RPMI medium and 10\% fetal calf serum. $5 \mathrm{ml}$ of the cell suspension was placed in either polystyrene tubes or 30-ml flat-bottomed flasks (Corning Glass Works, Corning, NY) with or without selected concentrations of IL-3. For incubation periods up to $3 \mathrm{~h}$, the cell suspensions in capped polystyrene tubes were placed in a shaking water bath at $37^{\circ} \mathrm{C}$. For longer incubation periods, the cell suspensions in flasks were incubated at $37^{\circ} \mathrm{C}$ in a humidified atmosphere of $5 \% \mathrm{CO}_{2}$ in air. At selected time intervals, the nonadherent cells were harvested by centrifugation at $400 \mathrm{~g}$ for $5 \mathrm{~min}$ at room temperature, washed once, and resuspended in Hepes-buffered RPMI medium and 10\% fetal calf serum. Cell number was determined visually in a hemocytometer and viability was evaluated by trypan blue exclusion.

Spleen colony assay. CFU-S were assayed by the method of Till and McCulloch (18). Syngeneic recipient mice were exposed to a lethal dose (1,050 rads) of whole body irradiation from a ${ }^{137} \mathrm{Cs}$ source (dose rate $126 \mathrm{rads} / \mathrm{min}$; gamma cell 40, Atomic Energy of Canada, Ottawa, Canada). $4 \mathrm{~h}$ later the mice were injected by tail vein with $2 \times 10^{4}$ viable nucleated marrow cells in $0.2 \mathrm{ml}$ of Hepes-buffered RPMI medium and $10 \%$ fetal calf serum. An inoculum of this size produced on average seven macroscopic surface colonies per spleen. With larger numbers of cells, the surface colonies were too crowded for accurate counting. 10 irradiated mice were injected for each experimental point except when simultaneous studies of spleen histology were performed. In these instances, 15 mice were injected and 5 were picked at random for the histologic studies. $11 \mathrm{~d}$ after injection, the mice were sacrificed and their spleens were excised. For surface colony counts, the spleens were immersed in Carnoy's solution and transferred to absolute ethanol after 24 $h$. Surface colonies were counted under low magnification $(\times 2)$ without knowledge of the experimental protocol. Results were expressed as the number of spleen colonies per $10^{6}$ cultured marrow cells. Mice irradiated with 1,050 rads but not injected with marrow cells served as controls for endogenous spleen colony formation. Endogenous spleen colony formation was negligible in that a single macroscopic colony occurred in only 8 of 133 control spleens in 15 separate experiments.

For histologic studies of spleen colony composition, the spleens were fixed in $10 \%$ buffered formalin and sectioned at 4- $\mu \mathrm{m}$ intervals and 810 sections were mounted serially on glass slides ( 10 slides per spleen) and stained with hematoxylin and eosin. Only spleens that contained a number of macroscopic colonies comparable to those enumerated by surface counting were examined microscopically. Spleen colony composition was analyzed according to the method of Silini et al. (19) and three to four spleens were evaluated for each experimental point.

Tritiated thymidine suicide studies $(1,20)$. Control and treated marrow cells were suspended in Hepes-buffered RPMI medium and $10 \%$ fetal calf serum at a concentration of $10^{6}$ cells $/ \mathrm{ml}$ with or without 20 or $100 \mu \mathrm{Ci} / \mathrm{ml}$ of $\left[{ }^{3} \mathrm{H}\right]$ methylthymidine $\left(\left[{ }^{3} \mathrm{H}\right] \mathrm{TdR}\right.$, sp act $25 \mathrm{Ci} / \mathrm{mmol}$; Research Products International Corp., Mount Prospect, IL) or $\left[{ }^{3} \mathrm{H}\right] \mathrm{TdR}$ and $200 \mu \mathrm{g} / \mathrm{ml}$ of unlabeled thymidine (TdR) and incubated in a shaking water bath at $37^{\circ} \mathrm{C}$ for $25 \mathrm{~min}$. After incubation, $10 \mathrm{ml}$ of Hepes-buffered
RPMI medium and $10 \%$ fetal calf serum containing $200 \mu \mathrm{g}$ of $\mathrm{TdR} / \mathrm{ml}$ was added to each tube, and the tubes were centrifuged at $400 \mathrm{~g}$ for 5 min at room temperature. The cell pellet was resuspended and washed in Hepes-buffered RPMI medium and $10 \%$ fetal calf serum containing $40 \mu \mathrm{g}$ of $\mathrm{TdR} / \mathrm{ml}$. The cells were then resuspended in Hepes-buffered RPMI medium and $10 \%$ fetal calf serum for the spleen colony assay.

Antibody treatment. Control and treated marrow cells were suspended at a concentration of $5 \times 10^{6}$ cells $/ \mathrm{ml}$ in Hepes-buffered RPMI medium and $10 \%$ fetal calf serum and incubated at $4^{\circ} \mathrm{C}$ with a 1:50 dilution of a monoclonal anti-mouse Thy 1.2 antibody (Becton, Dickinson \& Co., Mountain View, CA) or normal syngeneic mouse serum. After $45 \mathrm{~min}$ the cells were centrifuged at $400 \mathrm{~g}$ for $5 \mathrm{~min}$ at room temperature and resuspended in Hepes-buffered RPMI medium and $10 \%$ fetal calf serum in the presence of a 1:6 dilution of guinea pig complement (Microbiological Associates, Walkersville, MD) for $60 \mathrm{~min}$ at $37^{\circ} \mathrm{C}$. The reaction was stopped by placing the cells on ice. The treated cells were washed once with Hepes-buffered RPMI medium and $10 \%$ fetal calf serum before assay of CFU-S.

Reagents. The interleukin 3 employed in these experiments was purified to homogeneity according to previously published techniques (11) and diluted with RPMI medium and $10 \%$ fetal calf serum to a concentration of $20 \mathrm{U} / \mathrm{ml}$. Penicillin $(100 \mathrm{U} / \mathrm{ml})$ and streptomycin $(100 \mu \mathrm{g} / \mathrm{ml})$ (Gibco Laboratories) were present in all tissue culture media. 5-Fluorouracil (5-FU, Roche Laboratories, Nutley, NJ) was administered by tail vein at a dose of $150 \mathrm{mg} / \mathrm{kg}$ of body weight.

Statistical analysis. The significance of the experimental observations was assessed with Student's two-tailed $t$ test.

\section{Results}

When mouse marrow cells were incubated in vitro in RPMI medium and $10 \%$ fetal calf serum, there was a gradual decline in both cell number and day 11 CFU-S such that by $96 \mathrm{~h}$ only $20 \%$ of the initial inoculum and $13 \%$ of the CFU-S could be recovered from the nonadherent cell population (Figs. 1 and 2). Although the nonadherent cell population remained constant when the incubation period was extended to 192 or $264 \mathrm{~h}$, no day 11 CFU-S could be recovered at these times.

In contrast, when the marrow cells were incubated in the presence of IL-3 at a concentration of $20 \mathrm{U} / \mathrm{ml}$, the initial decline in nonadherent cell number was not only less marked but over a period of $192 \mathrm{~h}$, the number of nonadherent cells in the cultures increased (Fig. 1). Incubation of marrows with IL-3 for periods of 1-3 $\mathrm{h}$ did not alter the number of day $11 \mathrm{CFU}-\mathrm{S}$ as compared to control cultures, but the lymphokine prevented the marked decline in day $11 \mathrm{CFU}-\mathrm{S}$ observed after $24 \mathrm{~h}$ of in vitro culture (Fig. 2). A decline in spleen colony formation did occur in the IL-3 treated cultures over the first $48 \mathrm{~h}$ but by $72 \mathrm{~h}$ the number of day 11 CFU-S had begun to rise and by $96 \mathrm{~h}$ had returned to level in the initial inoculum. The increase in day 11 CFU-S between 72 and $96 \mathrm{~h}$ coincided with the nadir in nonadherent cell number. By $192 \mathrm{~h}$, the number of nonadherent cells had increased to its initial level but day 11 CFU-S were now markedly diminished. They could, however, still be detected at $264 \mathrm{~h}$ of culture, in contrast to cultures lacking IL-3.

After $96 \mathrm{~h}$ of culture without IL-3, the bulk of the nonadherent cell population consisted of granulocytes and small lymphocytes (Fig. $3 \mathrm{~A}$ ). In IL-3-treated cultures blast cells and promyelocytes predominated (Fig. $3 \mathrm{~B}$ ). By $192 \mathrm{~h}$ of culture, granulocytes in various stages of maturation composed the bulk of the nonadherent cell population. Many cells were in mitosis and macrophages, basophils, eosinophils, megakaryocytes, and nonnucleated erythrocytes were also present. The composition of the nonadherent cell population at $264 \mathrm{~h}$ was similar. Control 


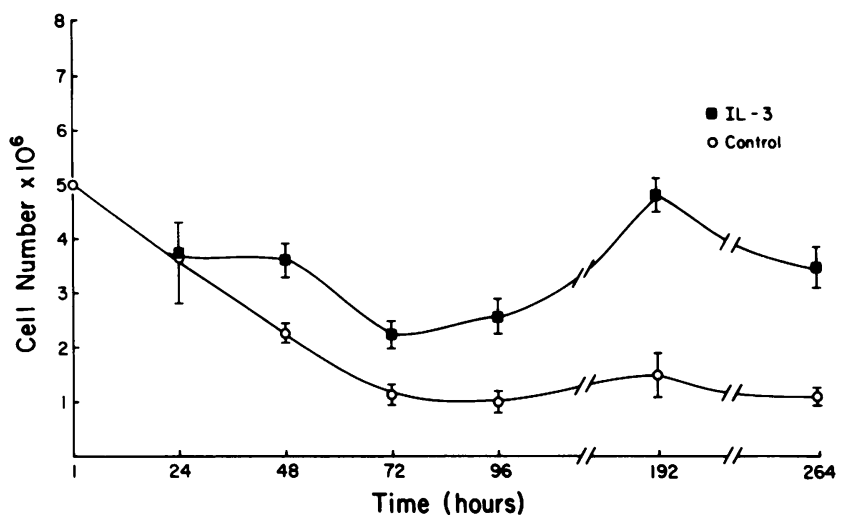

Figure 1. Effect of IL-3 on the in vitro survival of nonadherent marrow cells. Marrow cells were cultured in RPMI medium and $10 \%$ fetal calf serum in the presence or absence of IL-3 $(20 \mathrm{U} / \mathrm{ml})$. At the indicated times, the cultures were terminated. The number of nonadherent cells was determined by hemocytometer and a spleen colony assay was performed for day 11 CFU-S. The data represent the mean \pm standard error of the mean of two to six experiments. $(O)$ Control cells; ( $\boldsymbol{\square})$ IL-3-treated cells.

cultures at 192 and $264 \mathrm{~h}$ consisted mainly of macrophages (data not shown).

In both control and IL-3-treated cultures, an adherent cell population formed, which could only be detached incompletely with trypsin. At $96 \mathrm{~h}$, the adherent cell population was $<5 \%$ of the nonadherent cell population in both control and IL-3-treated cultures. An insufficient number of adherent cells was recovered from control cultures for spleen colony assay but no day 11 spleen colonies were formed by adherent cells from the IL-3treated cultures. At $264 \mathrm{~h}$, the number of adherent cells recovered with trypsin from control cultures was threefold greater than the number of nonadherent cells $\left(3.5 \times 10^{5}\right.$ cells vs. $1 \times 10^{5}$ cells). By contrast, in IL-3-treated cultures, the number of adherent cells recovered was $<20 \%$ of the nonadherent cell population $\left(6.8 \times 10^{5}\right.$ cells vs. $3.9 \times 10^{6}$ cells $)$. The adherent cell populations recovered from both control and IL-3 treated cultures were pure populations of macrophages.

To determine whether the survival of day $11 \mathrm{CFU}-\mathrm{S}$ in vitro

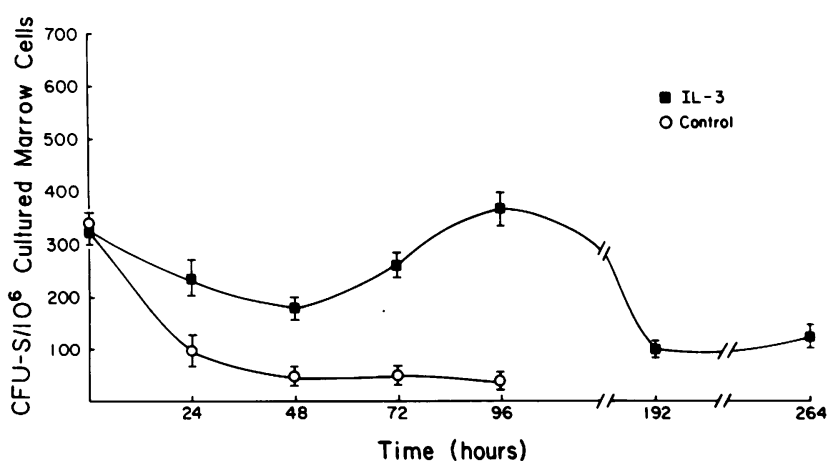

Figure 2. Effect of IL-3 on the in vitro survival of day 11 CFU-S. The data represent the mean \pm standard error of the mean of two to six experiments performed with marrow cells cultured for the indicated times in the presence or absence of IL-3 $(20 \mathrm{U} / \mathrm{ml})$. No spleen colonies were formed by control marrow cells at 192 and $264 \mathrm{~h}$ of culture. (O) Control cells; ( $\square$ ) IL-3-treated cells. required continuous exposure to IL-3, marrow cells were incubated with the lymphokine for periods of 1,4 , or $24 \mathrm{~h}$, washed, and reincubated in its absence. As shown in Table I, brief periods of exposure to IL-3 were insufficient to maintain the number of day $11 \mathrm{CFU}-\mathrm{S}$ at the level expected after $96 \mathrm{~h}$ of culture. However, exposure to the lymphokine for as little as $1 \mathrm{~h}$ increased the number of CFU-S present at $96 \mathrm{~h}$ above that found in control cultures, and with $24 \mathrm{~h}$ of exposure to IL-3 $\sim 50 \%$ of the expected number of CFU-S could be recovered at $96 \mathrm{~h}$.

In that the number of day $11 \mathrm{CFU}-\mathrm{S}$ present in cultures containing IL-3 fluctuated between 24 and $72 \mathrm{~h}$, we examined the responsiveness of marrow cells cultured for various periods of time to the lymphokine. As shown in Table II, when IL-3 was added to marrow cells that had been cultured in vitro for $24 \mathrm{~h}, \sim 50 \%$ of the day $11 \mathrm{CFU}-\mathrm{S}$ expected at $96 \mathrm{~h}$ were recovered. However, if the marrow cells were cultured for 48 or $72 \mathrm{~h}$ without IL-3, addition of the lymphokine yielded only $20 \%$ of the CFU-S expected at $96 \mathrm{~h}$.

The cyclic fluctuation in the number of day $11 \mathrm{CFU}-\mathrm{S}$ when marrow cells were cultured with IL-3 for $96 \mathrm{~h}$ suggested that the CFU-S were proliferating. To examine whether day $11 \mathrm{CFU}-\mathrm{S}$ were in cell cycle in IL-3-treated cultures, the TdR suicide technique was employed. Exposure of freshly harvested marrow cells to high specific activity $\left[{ }^{3} \mathrm{H}\right] \mathrm{TdR}$ did not diminish the recovery of day 11 CFU-S (Table III). However, when the marrow cells were cultured with IL-3 for $96 \mathrm{~h}$, exposure to $\left[{ }^{3} \mathrm{H}\right] \mathrm{TdR}$ resulted in a loss of $>20 \%$ of the day 11 CFU-S, indicating that a substantial proportion of the IL-3-treated day $11 \mathrm{CFU}-\mathrm{S}$ were in active cell cycle at that time.

The Thy 1.2 antigen has been demonstrated on early (day 8) CFU-S $(21,22)$ as well as on high proliferative potential colony-forming cells (23), BFU-E, and CFU-GM (24). We, therefore, examined the effect of a monoclonal antibody to the Thy 1.2 antigen on the interaction of IL-3 and day 11 CFU-S by means of the spleen colony assay. Exposure of freshly harvested marrow cells to Thy 1.2 antibody and complement did not influence the number of day $11 \mathrm{CFU}-\mathrm{S}$ recovered as determined by the spleen colony assay (Table IV). Exposure of marrow cells to the Thy 1.2 antibody and complement before incubation with the lymphokine for $96 \mathrm{~h}$ also did not diminish the number of CFU-S recovered. However, when the marrow cells were cultured with IL-3 for $96 \mathrm{~h}$ and then exposed to the Thy 1.2 antibody and complement, the number of day $11 \mathrm{CFU}-\mathrm{S}$ was significantly diminished (Table IV). Thus, as a consequence of exposure to IL-3, day 11 CFU-S became more sensitive to complement lysis in the presence of the anti-Thy 1.2 antibody.

To determine whether dose-response curve for the interaction of IL-3 with day 11 CFU-S in vitro was similar to that observed for other in vitro biologic effects of the lymphokine, the effect of various concentrations of the IL-3 on the recovery of day 11 CFU-S after $96 \mathrm{~h}$ of culture was examined. As shown in Fig. 4 , IL-3 promoted the proliferation of day $11 \mathrm{CFU-S}$ in vitro at concentrations ranging from 20 to $0.2 \mathrm{u} / \mathrm{ml}$. For comparison, the dose-response curve for the in vitro proliferation of an IL-3 dependent cell line is plotted for the same lot of IL-3. The parallel between the two dose-response curves suggests that both activities are functions of the same molecule.

IL-3 stimulates the in vitro proliferation of lineage-restricted erythroid, myeloid, and megakaryocytic progenitor cells (1315). To determine whether the lymphokine influenced the commitment of pluripotent hematopoietic stem cells to specific differentiation pathways, we examined the cellular composition of 


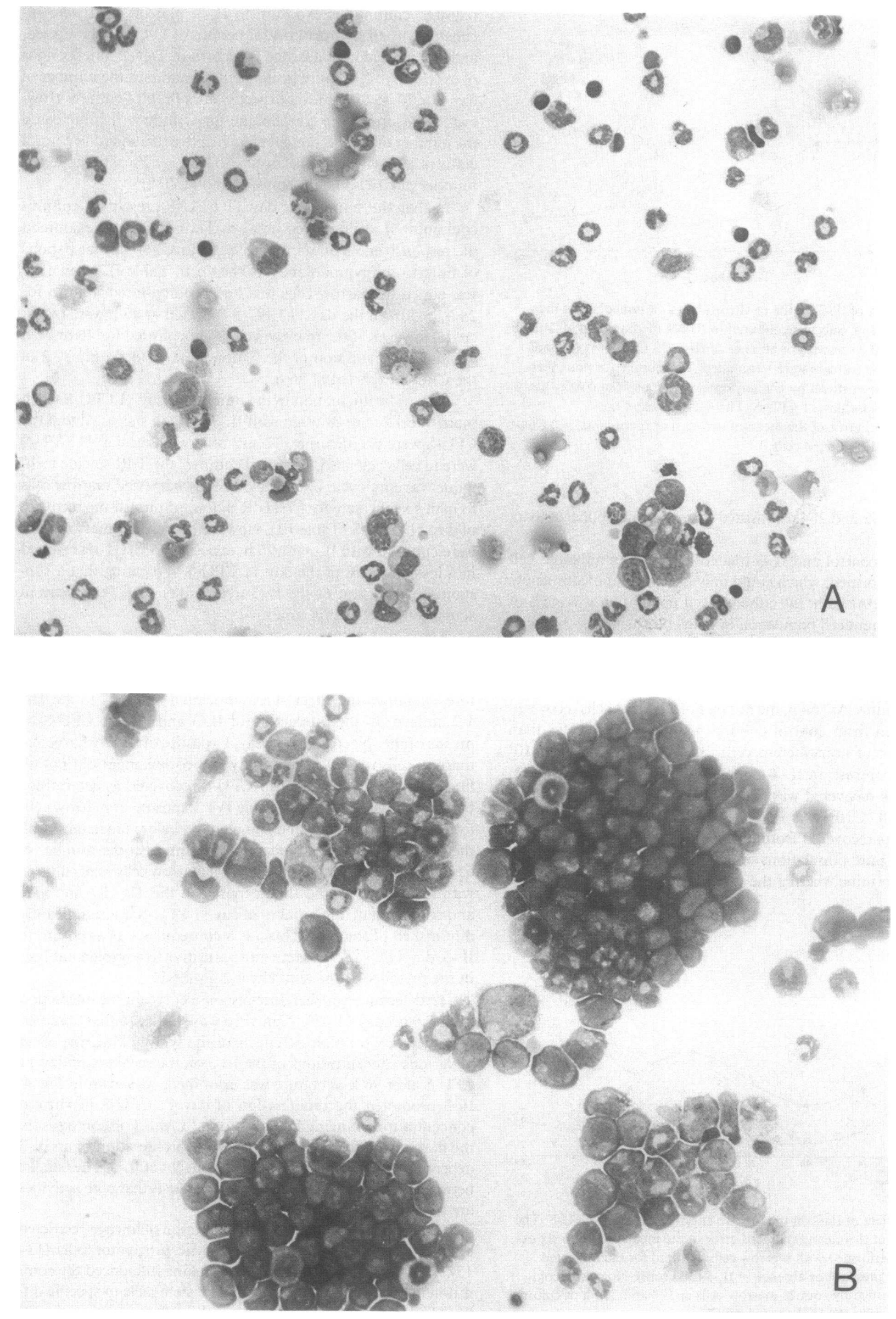


Table I. Effect of Duration of Exposure to IL-3 on the Survival of Day 11 CFU-S In Vitro

\begin{tabular}{ll}
\hline Duration of exposure to IL-3 & CFU-S/10 cultured marrow cells* \\
\hline$h$ & \\
None & $20 \pm 9$ \\
1 & $125 \pm 39 \ddagger$ \\
4 & $130 \pm 17 \S$ \\
24 & $180 \pm 34 \ddagger$ \\
96 & $370 \pm 50^{\| \prime}$ \\
\hline
\end{tabular}

Marrow cells were incubated in vitro with IL-3 $(20 \mathrm{U} / \mathrm{ml})$ for 1 , 4 , or $24 \mathrm{~h}$, washed, reincubated without IL-3, and harvested at $96 \mathrm{~h}$ for assay of day 11 CFU-S. As controls, marrow cells were incubated with or without IL-3 for $96 \mathrm{~h}$. The data represent the pooled results of three separate experiments.

* Mean \pm standard error of the mean.

$\ddagger$ Significantly different from control $P<0.05$.

$\S$ Significantly different from control $P<0.005$.

"Significantly different from control $P<0.001$.

the day 11 spleen colonies generated by marrow cells cultured in the presence of IL-3 for various periods of time. As shown in Table V, the proportion of erythroid, myeloid, megakaryocyte, or mixed colonies formed by marrow cells exposed to IL-3 was not different from that of untreated marrow cells regardless of the duration of exposure to the lymphokine. The number of mixed colonies was too small for statistical analysis of the different types of colonies, but there was no pattern with respect to the type of mixed colonies formed from IL-3-treated marrow cells as compared with untreated marrow cells (data not shown). No histologically unidentifiable colonies were present in either control spleens or the spleens of mice receiving IL-3-treated marrow cells.

Recent studies have indicated that CFU-S are heterogeneous with regard to their capacity for self-renewal and marrow repopulation. It was therefore of interest to determine whether IL-3 was restricted in its interaction with CFU-S to those that lack these features. Because CFU-S that survive exposure to 5fluorouracil (5-FU) have a high proliferative potential and the ability to repopulate irradiated marrow (25), we examined the effect of IL-3 on the in vitro proliferation of these cells. As shown in Table VI, day 11 CFU-S from the marrow of 5-FU-treated mice failed to proliferate in vitro in the absence of IL-3, whereas in its presence they responded in the same fashion as day 11 CFU-S from untreated mice (Table I).

\section{Discussion}

An in vivo clonal assay for pluripotent hematopoietic stem cells was established 25 years ago (18), but the regulatory mechanisms controlling their proliferation are still not fully defined. The development of in vitro clonal assays for pluripotent stem cells (6, 7) as well as culture techniques for their long-term maintenance in vitro (26) have, however, provided new insight into this issue.
Table II. Effect of Time of Addition

of IL-3 on CFU-S Survival In Vitro

\begin{tabular}{lccc}
\hline & \multicolumn{3}{c}{ CFU-S/10 cultured marrow cells* } \\
\cline { 2 - 4 } Time of addition & Expt. 1 & Expt. 2 & Expt. 3 \\
\hline None added & $55 \pm 11$ & $15 \pm 8$ & $15 \pm 8$ \\
At initiation of culture & $485 \pm 60$ & $420 \pm 45$ & $315 \pm 28$ \\
After 24 h & $280 \pm 40$ & $190 \pm 19$ & - \\
After 48 h & $85 \pm 30 \ddagger$ & $80 \pm 25$ & $60 \pm 16$ \\
After 72 h & $130 \pm 22$ & - & $50 \pm 9$ \\
\hline
\end{tabular}

Marrow cells were cultured in vitro, and at the times indicated IL-3 $(20 \mathrm{U} / \mathrm{ml})$ was added to the cultures. At $96 \mathrm{~h}$, all cultures were harvested for assay of day 11 CFU-S.

* Mean \pm standard error of the mean.

$\ddagger$ Not significantly different from control.

A requirement for medium conditioned by spleen cells or activated lymphocytes is a common feature of in vitro clonal assays for multipotent hematopoietic progenitor cells with a capacity for self-renewal $(6,7)$ as well as for lineage-restricted primitive erythroid, myeloid, and megakaryocytic progenitors $(9,10)$. Attempts to separate the activities in conditioned medium responsible for promoting the proliferation of the various progenitor cells have been unsuccessful $(27,28)$, suggesting that all these activities may be contained in a single regulatory molecule.

With the purification of IL-3, it soon became apparent that the biologic interactions of the lymphokine extended beyond its capacity to induce $20 \alpha$-hydroxysteroid dehydrogenase in its target cells. The lymphokine was not only able to induce and maintain lymphocyte cell lines (29) but also multipotent hematopoietic cell lines as well $(30,31)$. Furthermore, IL-3 supported the in vitro proliferation of mast cells (13) and stimulated the clonal growth of primitive erythroid, myeloid, and megakaryocytic progenitor cells (13-15). Thus, it exhibited many of the properties of spleen cell-conditioned medium but was biologically and biochemically distinct from known regulatory factors such as GM-colony-stimulating factor and erythropoietin.

Because of its broad spectrum of activity with respect to hematopoietic progenitor cells, we sought to determine whether IL-3 promoted the proliferation of pluripotent hematopoietic stem cells. Although previous studies indicated that IL-3, like spleen cell-conditioned medium (32) and cloned mast cell growth factor (17) enhanced spleen colony formation by mouse marrow cells and maintained the proliferation of CFU-S in vitro, only early (8-9 day) spleen colonies were examined $(14,16)$. Such colonies are known to be transient and not associated with cells that have marrow-repopulating ability (33). Interestingly, none of the multipotent factor-dependent hematopoietic cell lines induced by the lymphokine were capable of spleen colony formation $(30,31)$. In our studies, we assayed the formation of spleen colonies at 11 days, when the colonies are known to contain cells with the capacity for self-renewal and marrow repopulation $(27,33)$. Furthermore, to separate the effects of IL-3 on CFU-S from those that might be exerted by the culture system itself, we used culture conditions which by themselves do not support the proliferation of CFU-S (26).
Figure 3. (A) Wright-stained cytospin preparation of nonadherent marrow cells cultured in RPMI medium and $10 \%$ fetal calf serum for $96 \mathrm{~h} . \times 680$. (B) Wright-stained cytospin preparation of nonadherent marrow cells cultured in RPMI medium and $10 \%$ fetal calf serum in the presence of IL-3 $(20 \mathrm{U} / \mathrm{ml})$ for $96 \mathrm{~h} . \times 680$. 
Table III. Effect of IL-3 on the In Vitro Cell Cycle Status of Day 11 CFU-S

\begin{tabular}{ll}
\hline Treatment & $\begin{array}{l}\text { CFU-S } / 10^{6} \\
\text { cultured marrow cells* }\end{array}$ \\
\hline IL-3 & $375 \pm 13$ \\
IL-3 $+100 \mu \mathrm{Ci}\left[{ }^{3} \mathrm{H}\right] \mathrm{TdR}$ at $96 \mathrm{~h}$ & $255 \pm 47 \ddagger$ \\
$\mathrm{IL}-3+100 \mu \mathrm{Ci}\left[{ }^{3} \mathrm{H}\right] \mathrm{TdR}+200 \mu \mathrm{g}$ of & \\
$\quad \mathrm{TdR}$ at $96 \mathrm{~h}$ & $370 \pm 15$ \\
None & $315 \pm 35$ \\
$100 \mu \mathrm{Ci}\left[{ }^{3} \mathrm{H}\right] \mathrm{TdR}$ & $300 \pm 28$ \\
$100 \mu \mathrm{Ci}\left[{ }^{3} \mathrm{H}\right] \mathrm{TdR}+200 \mu \mathrm{g}$ TdR & $405 \pm 60$ \\
\hline
\end{tabular}

Marrow cells were incubated in vitro with IL-3 $(20 \mathrm{U} / \mathrm{ml})$ for $96 \mathrm{~h}$ and then exposed to $\left[{ }^{3} \mathrm{H}\right] \mathrm{TdR}$ (Sp Act $25 \mathrm{Ci} / \mathrm{mmol}$ ) without or with cold TdR before spleen colony assay. As controls, fresh marrow cells were exposed to $\left[{ }^{3} \mathrm{H}\right] \mathrm{TdR}$ with or without $\mathrm{TdR}$ immediately before spleen colony assay.

* Mean \pm standard error of the mean.

$\ddagger P<0.05$; cell kill $=27 \%$.

Under these conditions, IL-3 promoted the proliferation of day 11 CFU-S and maintained nonadherent cell number as well in contrast to cultures lacking the lymphokine. Indeed, a single addition of IL-3 was sufficient to maintain the nonadherent cell population for $264 \mathrm{~h}$ and although diminished in quantity, day 11 CFU-S could still be recovered at that time.

The dose-response curve for CFU-proliferation in vitro by IL-3 was identical to that for the proliferative effect of the lymphokine on factor-dependent cell lines indicating that both activities were the properties of a single molecule. Failure of pretreatment with a Thy 1.2 antibody and complement to abolish the effect of IL-3 suggests that the lymphokine does not require

Table IV. Effect of Thy 1.2 Antibody and

Complement on Day 11 Spleen Colony Formation by Marrow Cells Exposed to IL-3 In Vitro

\begin{tabular}{|c|c|}
\hline Treatment & $\begin{array}{l}\text { CFU-S/10 } \\
\text { cultured marrow cells* }\end{array}$ \\
\hline Normal mouse serum $+C^{\prime}$ before IL-3 & $383 \pm 34 \ddagger$ \\
\hline Thy 1.2 antibody $+C$ before IL-3 & $355 \pm 22 \ddagger$ \\
\hline IL-3 $(96 \mathrm{~h})$ & $338 \pm 28 \ddagger$ \\
\hline Normal mouse serum $+C^{\prime}$ after IL-3 $(96 \mathrm{~h})$ & $350 \pm 20 \ddagger$ \\
\hline Thy 1.2 antibody $+C^{\prime}$ after IL-3 $(96 \mathrm{~h})$ & $195 \pm 27 \S$ \\
\hline $\begin{array}{l}\text { Normal mouse serum }+C^{\prime} \text { without } \\
\text { incubation in vitro }\end{array}$ & $416 \pm 24 \ddagger$ \\
\hline $\begin{array}{l}\text { Thy } 1.2 \text { antibody }+C^{C} \text { without incubation } \\
\text { in vitro }\end{array}$ & $362 \pm 23 \ddagger$ \\
\hline
\end{tabular}

Marrow cells were treated with either normal mouse serum or Thy 1.2 antibody and complement (C) before culture in vitro with IL-3 (20 U/ $\mathrm{ml}$ ) or after $96 \mathrm{~h}$ of culture with IL-3. As controls, fresh marrow cells were treated with either normal mouse serum or Thy 1.2 antibody and $\mathrm{C}$ immediately before the spleen colony assay.

* Mean \pm standard error of the mean.

$\ddagger$ Not significantly different.

$\S P<0.001$.

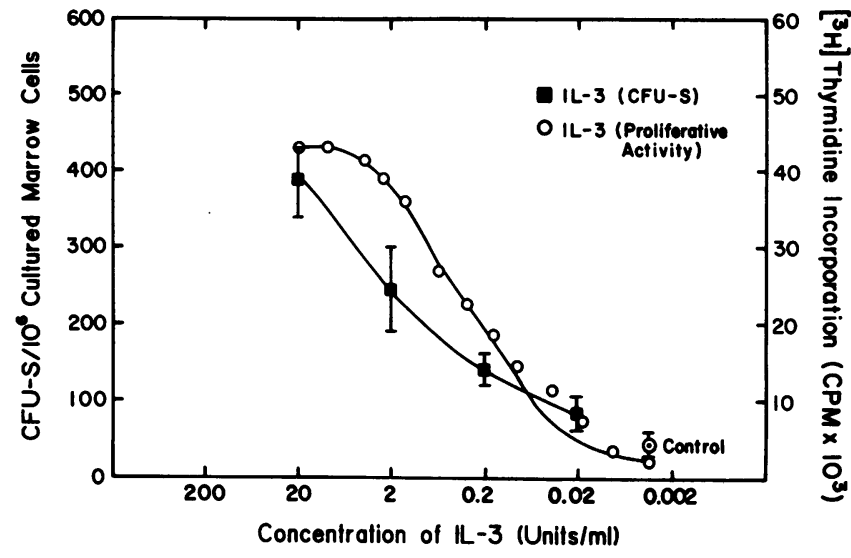

Figure 4. Dose-response curves for IL-3-mediated proliferation of day $11 \mathrm{CFU}-\mathrm{S}$ in vitro and IL-3-mediated factor-dependent cell line proliferation in vitro. The spleen colony assay was performed on marrow cells cultured in vitro with various concentrations of IL-3 for $96 \mathrm{~h}$. The data represent the mean \pm standard error of the means of three experiments and are superimposed on the titration curve for factor-dependent cell line proliferation (13) for the same lot of IL-3. (D) IL-3treated CFU-S; $(\odot)$ control CFU-S; (O) IL-3-treated factor-dependent cell line proliferation.

Thy 1.2 antigen-bearing cells for its interaction with day $11 \mathrm{CFU}$ S. It is likely that the CFU-S responding to IL-3 were from the nonadherent cell population, in that an established adherent cell layer was not present in our cultures and the adherent cell population consisted of macrophages that were devoid of spleen colony-forming activity.

During the course of in vitro culture in the presence of IL3 , there were significant fluctuations in the concentration of day $11 \mathrm{CFU}-\mathrm{S}$ and nonadherent cell number. In the absence of an

Table V. Distribution of Spleen Colonies by Cell Composition in Mice Receiving Marrow Cells Cultured in the Presence or Absence of IL-3

\begin{tabular}{lllll}
\hline & \multicolumn{3}{l}{ Spleen colony composition* } & \\
\cline { 2 - 5 } Treatment & Erythroid & Myeloid & Megakaryocyte & Mixed \\
\hline & $\%$ & $\%$ & $\%$ & $\%$ \\
None & $60 \pm 0.7$ & $24 \pm 5.7$ & 4 & $14 \pm 4.2$ \\
IL-3 for 1 h & $52 \pm 10.7$ & $33 \pm 5.0$ & 6 & 25 \\
None & $61 \pm 10.9$ & $37 \pm 1.6$ & 5 & $11.3 \pm 0.9$ \\
IL-3 for $3 \mathrm{~h}$ & $43 \pm 3.8$ & $35 \pm 4.6$ & $5.3 \pm 0.9$ & $16.3 \pm 7.4$ \\
None & - & - & - & - \\
IL-3 for $96 \mathrm{~h}$ & $56 \pm 4.5$ & $22 \pm 4.8$ & $4.3 \pm 2.1$ & $17.6 \pm 2.3$ \\
\hline
\end{tabular}

Marrow cells were cultured in the presence or absence of IL-3 (20 U/ $\mathrm{ml}$ ) for the indicated times before spleen colony assay. The spleens were prepared for histologic analysis as indicated in Methods. Data for each experimental point were derived from microscopic examination of 61-91 colonies from 7-10 spleens. There were an insufficient number of colonies for quantitative analysis of cell composition for 96-h controls.

* Mean \pm standard error of the mean.

‡ Erythroid-myeloid, megakaryocyte-myeloid, erythroid-myeloidmegakaryocyte. 
Table VI. Effect of IL-3 on the In Vitro Survival of Day 11 CFU-S from 5-FU-treated Marrow

\begin{tabular}{lcc}
\hline & \multicolumn{2}{c}{ CFU-S/10 cultured marrow cells* } \\
\cline { 2 - 3 } Additions to culture & Expt. 1 & Expt. 2 \\
\hline 5-FU-treated mice & & \\
None & $40 \pm 27$ & $80 \pm 22$ \\
IL-3 & $490 \pm 32$ & $400 \pm 46$ \\
Control mice & & \\
None & - & $15 \pm 9$ \\
IL-3 & $360 \pm 12$ & $315 \pm 28$ \\
\hline
\end{tabular}

Marrow cells harvested from mice that had received 5-FU $(150 \mathrm{mg} /$ $\mathrm{kg}$ ) intravenously $3 \mathrm{~d}$ previously were incubated in vitro with or without IL-3 $(20 \mathrm{U} / \mathrm{ml})$. After $96 \mathrm{~h}$ the cells were harvested for assay of day 11 CFU-S. Control cultures contained marrow cells from untreated mice.

* Mean \pm standard error of the mean.

established adherent cell layer these fluctuations cannot be attributed to an influx of cells from that source. The decline in CFU-S during the first $48 \mathrm{~h}$ of culture in the presence of a saturating concentration of IL-3 suggested that only a portion of the CFU-S population was able to respond to the lymphokine. This was confirmed by the experiments in which exposure to IL-3 was either limited in duration or initiated after the cells had been cultured in vitro for at least $24 \mathrm{~h}$. In each instance, no more than $50 \%$ of the expected number of CFU-S could be recovered at $96 \mathrm{~h}$ in comparison to cells which were continually exposed to the lymphokine. Because as little as $1 \mathrm{~h}$ of exposure to IL-3 was sufficient to maintain CFU-S in culture for $96 \mathrm{~h}$, it is unlikely that responsiveness to the lymphokine was related to duration of exposure. Rather it appears that the stem cell population was heterogeneous in its ability to proliferate in response to IL-3. This is in accord with the observations of Suda et al. (34). The subsequent increase in CFU-S concentration during the second $48 \mathrm{~h}$ of culture probably represents the emergence of a new cohort of stem cells responsive to the lymphokine.

Although stem cells are heterogeneous in their ability to proliferate in response to IL-3, they appear to require the lymphokine for survival in vitro. In the absence of IL-3, CFU-S concentration declined by $80 \%$ within the first $48 \mathrm{~h}$ of culture. Although the CFU-S concentration at 48 and $72 \mathrm{~h}$ was higher in cultures containing IL-3 than in control cultures, when addition of the lymphokine was delayed for 48-72 $\mathrm{h}$, the concentration of CFU-S persisting at $96 \mathrm{~h}$ fell markedly. This suggests that IL-3 was required not only for stem cell proliferation but also for maintenance of stem cells in vitro as well.

The cyclic behavior of the CFU-S in vitro in the presence of IL-3 is of interest with respect to the proposed instructive role of the hematopoietic microenvironment in regulating stem cell proliferation. Lord and co-workers $(35,36)$ have identified soluble factors in normal and regenerating bone marrow that respectively inhibit or stimulate CFU-S proliferation. Such factors have also been identified in vitro in long-term marrow cultures after medium replenishment (37). Cycling occurred in our cultures in the absence of an established adherent layer or manipulation of the culture medium. Furthermore, there is no a priori reason to assume that levels of any stimulatory or inhibitory factors were fluctuating in our cultures. Thus, while such factors may be operative in vivo, they are probably not obligatory for CFU-S proliferation. The cyclic behavior of the CFU-S we observed may be an intrinsic property of hematopoietic cells as previously postulated (38).

The sequential juxtaposition of the zenith and nadir in concentration of both CFU-S and nonadherent cells suggested a precursor-progeny relationship. This was supported by the composition of the nonadherent cell population at these times; during maximal CFU-S proliferation, blast cells and promyelocytes predominated while differentiating granulocytes composed the bulk of the nonadherent cells during maximal expansion of that population. The decline in spleen colony-forming activity during the initial period of culture also supports the contention that a portion of the stem cell population was differentiating. However, because IL-3 stimulates the proliferation of committed (39) as well as pluripotent progenitor cells, definite proof of a precursor-progeny relationship between these populations in our cultures cannot be established from our data.

Because IL-3 promotes the growth of lineage-restricted progenitor cells and because not all CFU-S have the capacity for self-renewal or marrow repopulation, it was important to determine whether IL-3 interacted with CFU-S with these characteristics. Indeed, some investigators have postulated that IL3 may not interact with the most primitive hematopoietic progenitor cells (40). CFU-S persisting in the marrow of mice treated with 5-FU have a high proliferative and marrow-repopulating capacity (25) and are thought to represent an antigenically distinct cell population (41). We found that marrow cells obtained from 5-FU-treated mice responded to IL-3 in vitro in the same manner as normal marrow cells. Thus IL-3 interacts with primitive stem cells with a high proliferative capacity and marrowrepopulating potential as well as with lineage-restricted progenitor cells.

Previous studies have demonstrated that early (day 8) CFU$\mathrm{S}$, high proliferative potential colony-forming cells, BFU-E, and CFU-GM express the Thy 1.2 antigen (21-24). We also detected the Thy 1.2 antigen on day $11 \mathrm{CFU}-\mathrm{S}$ as measured by sensitivity to complement lysis but only after exposure to IL-3. Whether the change in susceptibility to complement lysis in the presence of the anti-Thy 1.2 antibody is related to an IL-3-induced change in cell cycle status is unknown, and further studies of Thy 1.2 antigen expression on day 11 CFU-S are indicated.

Ogawa and co-workers $(42,43)$ have presented data based on in vitro studies that support a stochastic mechanism for stem cell differentiation. Because IL-3 promotes the proliferation and differentiation of a variety of lineage-restricted hematopoietic progenitor cells, it was of interest to determine whether exposure to the lymphokine for various periods of time influenced the commitment of pluripotent stem cells to a particular differentiation pathway. Analysis of spleen colony histology failed to reveal any change in the cell composition of colonies formed by IL-3-treated cells as compared with controls even after $96 \mathrm{~h}$ of exposure to the lymphokine. This result provides additional support for the hypothesis that commitment to differentiation by pluripotent stem cells occurs stochastically.

Taken together, our data demonstrate that IL-3 promotes the survival and proliferation of pluripotent hematopoietic stem cells in vitro without altering their commitment program and thus establishes the lymphokine as the first physiologic regulatory molecule to be identified with these properties. Because IL-3 is an immunologic regulatory protein, the biologic significance of 
its ability to promote the proliferation of pluripotent hematopoietic stem cells remains to be determined, although this may relate to enhancement of $\mathrm{T}$ cell production. Regardless of its biologic role, IL-3 should prove to be an important reagent for studying stem cell behavior and for obtaining cell populations enriched with respect to their stem cell content. In that IL-3 increases the number of stem cells in cell cycle, it may also be useful in enhancing the incorporation of new genetic material into these cells (44).

\section{Acknowledgments}

The excellent technical assistance of Mrs. Mary Ann Isaacs and Mrs. Evelyn Connor is acknowledged with gratitude.

This work was supported in part by grant AM-16702 from the National Institute of Arthritis, Diabetes, Digestive and Kidney Diseases and sponsored by the National Cancer Institute under contract no. NO1CO-75380 with Litton Bionetics, Inc.

\section{References}

1. Becker, A. T., E. A. McCulloch, L. Siminovitch, and J. E. Till. 1965. The effect of differing demands for blood cell production on DNA synthesis by hemopoietic colony-forming cells of mice. Blood. 26:296308.

2. Chervenick, P. A., and D. R. Boggs. 1971. Patterns of proliferation and differentiation of hematopoietic stem cells after compartment depletion. Blood. 37:568-580.

3. Byron, J. W. 1975. Manipulation of the cell cycle of the hemopoietic stem cell. Exp. Hematol. 3:44-53.

4. Cerny, J. 1974. Stimulation of bone marrow haemopoietic stem cells by a factor from activated T cells. Nature (Lond.). 249:63-66.

5. Metcalf, D., C. R. Johnson, and T. Mandel. 1978. Colony formation in agar by multipotential hemopoietic cells. J. Cell Physiol. 98:401-420.

6. Humphries, R. K., P. B. Jacky, F. J. Dill, A. C. Eaves, and C. J. Eaves. 1979. CFU-S in individual erythroid colonies derived in vitro from adult mouse marrow. Nature (Lond.). 279:718-720.

7. Nakahata, T., and M. Ogawa, 1982. Identification in culture of a class of hemopoietic colony-forming units with extensive capability to self-renew and generate multipotential hemopoietic colonies. Proc. Natl. Acad. Sci. USA. 79:3843-3847.

8. Wagemaker, G., S. Merchav, and H. Burger. 1982. Multiplication of pluripotent hemopoietic stem cells induced by purified stem cell activating factor (SAF) in serum free suspension cultures. Exp. Hematol. 10(Suppl.)11:162a. (Abstr.)

9. Iscove, N. N. 1978. Erythropoietin-independent stimulation of early erythropoiesis in adult bone marrow cultures by conditioned media from lectin-stimulated mouse spleen cells. In Hematopoietic Cell Differentiation. D. W. Golde, M. J. Cline, D. Metcalf, and C. F. Fox, editors. Academic Press, Inc., New York. 37-52.

10. Metcalf, D., and G. R. Johnson. 1978. Production by spleen and lymph node cells of conditioned medium with erythroid and other hemopoietic colony-stimulating activity. J. Cell Physiol. 96:31-42.

11. Ihle, J. N., J. Keller, L. Henderson, F. Klein, and E. Palaszynski. 1982. Procedures for the purification of interleukin 3 to homogeneity. J. Immunol. 129:2431-2436.

12. Ihle, J. N., L. Pepersack, and L. Rebar. 1981. Regulation of T cell differentiation: in vitro induction of $20 \alpha$-hydroxysteroid dehydrogenase in splenic lymphocytes is mediated by a unique lymphokine. $J$. Immunol. 126:2184-2189.

13. Ihle, J. N., J. Keller, S. Oraszlan, L. E. Henderson, T. D. Copeland, F. Fitch, M. B. Prystowsky, E. Goldwasser, J. Schrader, E. Palaszynski, M. Dy, and B. Lebel. 1983. Biologic properties of hemogeneous interleukin 3. J. Immunol. 131:282-287.
14. Goldwasser, E., J. N. Ihle, M. B. Prystowski, J. Rick and G. Van Zant. 1983. The effect of interleukin-3 on hemopoietic precursor cells. In Normal and Neoplastic Hematopoiesis. Alan R. Liss, New York. 301-309.

15. Quesenberry, P. J., J. N. Ihle, and E. McGrath. 1985. The effect of interleukin 3 and GM-CSA-2 on megakaryocyte and myeloid clonal colony formation. Blood. 65:214-217.

16. Garland, J. M., and S. Crompton. 1983. A preliminary report: preparations containing interleukin-3 (IL-3) promote proliferation of multipotential stem cells (CFU-S) in the mouse. Exp. Hematol. 11:757761.

17. Rennick, D. M., F. D. Lee, T. Yokota, K-I. Arai, H. Cantor, and G. J. Nabel. 1985. A cloned mast cell growth factor cDNA encodes a multilineage hematopoietic growth factor: Multiple activities of interleukin 3. J. Immunol. 134:910-914.

18. Till, J. E., and E. A. McCulloch. 1961. A direct measurement of the radiation sensitivity of normal mouse bone marrow cells. Radiat. Res. 14:213-222.

19. Silini, G., S. Pons, and L. V. Pozzi, 1968. Quantitative histology of spleen colonies in irradiated mice. Br. J. Haematol. 14:489-506.

20. Gregory, C. J., and A. C. Eaves. 1978. Three stages of erythropoietic progenitor cell differentiation distinguished by a number of physical and biologic properties. Blood. 51:527-537.

21. Basch, R. S., and J. W. Berman. 1982. Thy-1 determinants are present on many murine hematopoietic cells other than T cells. Eur. $J$. Immunol. 12:359-364.

22. Schrader, J. W., F. Battye, and R. Scollay. 1982. Expression of Thy 1.2 antigen is not limited to $T$ cells in cultures of mouse hemapoietic cells. Proc. Natl. Acad. Sci. USA. 79:4161-4165.

23. Boswell, H. S., P. M. Wade, Jr., and P. J. Quesenberry. 1984. Thy-1 antigen expression by murine high-proliferative capacity hematopoietic progenitor cells. J. Immunol. 133:2940-2949.

24. Miller, B. A., J. M. Lipton, D. C. Linch, S. J. Burakoff, and D. G. Nathan. 1985. Thy- 1 is a differentiation antigen that characterizes immature murine erythroid and myeloid hematopoietic progenitors. $J$. Cell Physiol. 123:25-32.

25. Bradley, T. R., and G. S. Hodgson. 1979. Properties of haematopoietic stem cells surviving 5-fluorouracil treatment: evidence for a pre-CFU-S cell? Nature (Lond.). 281:381-382.

26. Dexter, T. M., E. G. Wright, F. Krizsa, and L. G. Lajtha. 1977. Regulation of haemopoietic stem cell proliferation in long term bone marrow cultures. Biomedicine (Paris). 27:244-349.

27. Iscove, N. N., C. A. Roitsch, N. Williams, and L. J. Guibert. 1982. Molecules stimulating early red cell, granulocyte, macrophage, and megakaryocyte precursors in culture: similarity in size, hydrophobicity, and charge. J. Cell Physiol. (Suppl.)1:65-78.

28. Burgess, A. W., D. Metcalf, S. H. M. Russell, and N. A. Nicola. 1980. Granulocyte/macrophage-megakaryocyte-eosinophil- and erythroid-colony-stimulating factors produced by mouse spleen cells. Biochem. J. 185:301-314.

29. Ihle, J. N., J. Keller, J. S. Greenberger, L. Henderson, R. A. Yetter, H. C. Morse II. 1982. Phenotypic characteristics of cell lines requiring interleukin 3 for growth. J. Immunol. 129:1377-1383.

30. Dexter, T. M., J. Garland, D. Scott, E. Scolnick, and D. Metcalf. 1980. Growth of factor-dependent hemopoietic precursor cell lines. $J$. Exp. Med. 152:1036-1047.

31. Greenberger, J. S., R. J. Eckner, M. Sakakeeny, P. Marks, D. Reid, G. Nobel, A. Hapel, J. Ihle, and K. Humphries. 1983. Interleukin3 dependent hematopoietic progenitor cell lines. Fed. Proc. 452-27622771.

32. Schrader, J. W., and I. Clark-Lewis. 1982. A T cell-derived factor stimulating multipotential hemopoietic stem cells: molecular weight and distinction from $\mathrm{T}$ cell growth factor and $\mathrm{T}$ cell-derived granulocytemacrophage colony-stimulating factor. J. Immunol. 129:30-35.

33. Magli, M. C., N. N. Iscove, and N. Odartchenko. 1982. Transient nature of early haematopoietic spleen colonies. Nature (Lond.). 295: 527-529.

34. Suda, T., J. Suda, and M. Ogawa. 1983. Proliferative kinetics 
and differentiation of murine blast cell colonies in culture: evidence for variable $\mathrm{G}_{0}$ periods and constant doubling rates of early pluripotent hemopoietic progenitors. J. Cell Physiol. 117:308-318.

35. Lord, B. I., K. J. Mori, E. G. Wright, and L. G. Lajtha. 1976. An inhibitor of stem cell proliferation in normal bone marrow. $B r . J$. Haematol. 34:441-445.

36. Lord, B. I., K. J. Mori, and E. G. Wright. 1977. A stimulator of stem cell proliferation in regenerating bone marrow. Biomedicine (Paris). 27:223-226.

37. Toksoz, D., T. M. Dexter, B. I. Lord, E. G. Wright, and L. G. Lajtha. 1980. The regulation of hemopoiesis in long term bone marrow cultures. II. Stimulation and inhibition of stem cell proliferation. Blood. 55:931-936

38. King-Smith, E. A., and A. Morley. 1970. Computer simulation of granulopoiesis: normal and impaired granulopoiesis. Blood. 36:254262.

39. Prystowsky, M. B., G. Otten, M. F. Naujokas, J. Vardiman, J. N. Ihle, E. Goldwasser, and F. Fitch. 1984. Multiple hemopoietic lineages are formed after stimulation of mouse bone marrow precursor cells with interleukin 3. Am. J. Pathol. 117:171-179.

40. Stanley, E. J., and P. T. Jubinsky. 1984. Factors affecting the growth and differentiation of hemopoietic cells in culture. Clin. Haematol. 13:329-348.

41. Harris, R. A., P. M. Hogarth, L. J. Wadeson, P. Collins, I. F. C. McKenzie, and D. G. Penington. 1984. An antigenic difference between cells forming early and late haematopoietic spleen colonies (CFU-S) $\mathrm{Na}$ ture (Lond.). 307:638-640.

42. Nakahata, T., A. J. Gross, and M. Ogawa. 1982. A stochastic model of self-renewal and commitment to differentiation of the primative hemopoietic stem cells in culture. J. Cell Physiol. 113:455-458.

43. Suda, T., J. Suda, and M. Ogawa. 1984. Disparate differentiation in mouse hemopoietic colonies derived from paired progenitors. Proc. Natl. Acad. Sci. USA. 81;2520-2524.

44. Williams, D. A., I. R. Lemischka, D. G. Nathan, and R. C. Mulligan. 1984. Introduction of new genetic material into pluripotent haematopoietic stem cells of the mouse. Nature (Lond.). 310:476-480. 